\title{
Transepithelial flux of early and advanced glycation compounds across Caco-2 cell monolayers and their interaction with intestinal amino acid and peptide transport systems
}

\author{
Simone Grunwald ${ }^{1,2}$, René Krause ${ }^{2}$, Mandy Bruch ${ }^{1}$, Thomas Henle ${ }^{2}$ and Matthias Brandsch ${ }^{1} *$ \\ ${ }^{1}$ Membrane Transport Group, Biozentrum, Martin-Luther-University Halle-Wittenberg, Weinbergweg 22, D-06120 Halle, Germany \\ ${ }^{2}$ Institute of Food Chemistry, Technical University Dresden, D-01062 Dresden, Germany
}

(Received 5 May 2005 - Revised 30 September 2005 - Accepted 10 November 2005)

\begin{abstract}
Maillard products arise from condensation reactions between amino acids or proteins with reducing sugars during food processing. As ubiquitous components of human food, these early or advanced glycation products may be subject to intestinal absorption. The present study was performed to investigate the intestinal uptake of Maillard products and to determine whether they are substrates for peptide and amino acid transporters expressed at the apical membrane of Caco-2 cells. At a concentration of $10 \mathrm{~mm}, N^{\varepsilon}$-(carboxymethyl)-L-lysine, $N^{\alpha}$-hippuryl- $N^{\varepsilon}$-(1-deoxy-D-fructosyl)-L-lysine, $N^{\alpha}$-hippuryl- $N^{\varepsilon}$-(carboxymethyl)-L-lysine and $N^{\varepsilon}$-(1-deoxy-D-fructosyl)-L-lysine inhibited the $\left[{ }^{14} \mathrm{C}\right]$ glycylsarcosine uptake mediated by the $\mathrm{H}^{+}$-peptide co-transporter PEPT1 by 13 to $45 \%$. For $N^{\varepsilon}$-(1-deoxy-D-fructosyl)-L-lysine, an inhibitory constant of $8.7 \mathrm{~mm}$ was determined, reflecting a low affinity to PEPT1 in comparison with natural dipeptides. Uptake of L- $\left[{ }^{3} \mathrm{H}\right]$ lysine was weakly affected by $N^{\varepsilon}$-(carboxymethyl)-L-lysine, $N^{\alpha}$-hippuryl-L-lysine and $N^{\alpha}$-hippuryl- $N^{\varepsilon}$-(carboxymethyl)-L-lysine but strongly inhibited by $N^{\varepsilon}$-(1-deoxy-D-fructosyl)-L-lysine $(81 \%)$. None of the Maillard products was able to inhibit the uptake of L- $\left[{ }^{3} \mathrm{H}\right]$ leucine by more than $15 \%$. We also studied the transepithelial flux of Maillard products across Caco-2 cell monolayers cultured on permeable filters. The flux rates of Maillard products ranged from 0.01 to $0.3 \% / \mathrm{cm}^{2}$ per $\mathrm{h}$ and were shown to be much lower than those of carrier substrates such as glycylsarcosine, L-proline and the space marker $\left[{ }^{14} \mathrm{C}\right]$ mannitol. We conclude that the Maillard products investigated in the present study are neither transported by PEPT1 nor by carriers for neutral amino acids. The low transepithelial flux measured for these compounds most probably occurs by simple diffusion.
\end{abstract}

Advanced glycation reactions: Maillard products: Membrane transport: Resorption: Caco-2 cells

During heating or storage of food, the nutritional quality of proteins is significantly influenced by the so-called Maillard reaction (Friedman, 1996; Gerrard, 2002). This reaction, also referred to as non-enzymic browning or 'glycation', occurs between reducing carbohydrates or their degradation products with amino acid side chains. Primary targets of such posttranslational modifications are the $\varepsilon$-amino group of lysine and the guanidino group of arginine (Fig. 1; Henle \& Miyata, 2003).

Besides the 'early' glycation compounds, namely the aminoketoses or 'Amadori compounds' $N^{\varepsilon}$-(1-deoxy-D-fructosyl)-Llysine (FruLys) and $N^{\varepsilon}$-lactuloselysine, several reaction products of 'advanced' glycation reactions (advanced glycation end products; AGE) have been demonstrated in food (Henle, 2003). Quantification of individual glycation compounds might serve as a tool for controlling the impact of food processing and storage on the quality of foods (Krause et al. 2003).

It has been speculated that dietary Maillard compounds are a 'risk factor' for human health (Koschinsky et al. 1997; He et al. 1999). Hence, questions arise regarding the intake of dietary AGE via the daily food and their possible (patho)physiological role (Erbersdobler \& Faist, 2003). The formation of AGE in vivo contributes to the pathogenesis of diabetes, uraemia and ageing (Raj et al. 2000; Henle \& Miyata, 2003). However, since Maillard compounds are also produced endogenously in the human organism, their identification in human tissues and body fluids does not necessarily mean that these compounds had been taken up with the diet.

The daily intake of glycation compounds can be as high as 0.5 to $1.2 \mathrm{~g}$ for the Amadori compound FruLys and 25 to $75 \mathrm{mg}$ for the AGE pyrraline and $N^{\varepsilon}$-(carboxymethyl)-L-lysine (CML) (Henle, 2003). Only preliminary studies concerning digestion, resorption and elimination of AGE-modified food proteins have been published; initial rat feeding studies using proteins radioactively labelled by heating with $\left[{ }^{14} \mathrm{C}\right] \mathrm{glu}-$ cose gave evidence for a very low resorption rate. Less than $3 \%$ of the ingested radioactivity was measured in the urine of rats (Valle-Riestra \& Barnes, 1970; Finot \& Magnenat, 1981). Studies with human volunteers showed that the faecal excretion is about $1 \%$ of orally administered FruLys and the

Abbreviations: AGE, advanced glycation end product; CML, $N^{\varepsilon}$-(carboxymethyl)-L-lysine; FruLys, $N^{\varepsilon}$-(1-deoxy-D-fructosyl)-L-lysine; Gly-Sar, glycylsarcosine; HipCML, $N^{\alpha}$-hippuryl- $N^{\varepsilon}$-(carboxymethyl)-L-lysine; HipFruLys, $N^{\alpha}$-hippuryl- $N^{\varepsilon}$-(1-deoxy-D-fructosyl)-L-lysine; HipLys, $N^{\alpha}$-hippuryl-L-lysine; IC 50 , 50\% inhibitory concentration.

* Corresponding author: Dr Matthias Brandsch, fax +49 345552 7258, email matthias.brandsch@biozentrum.uni-halle.de 


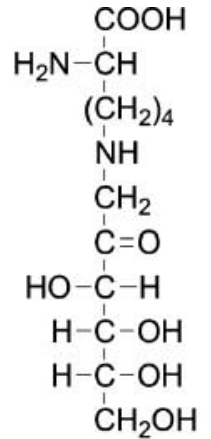

(a)

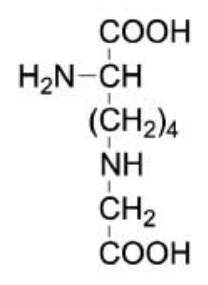

(c)

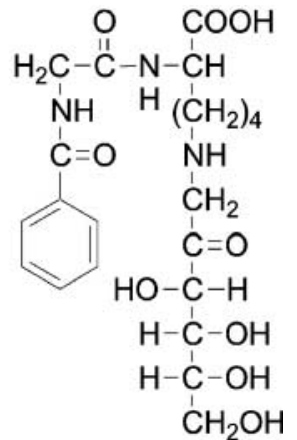

(b)

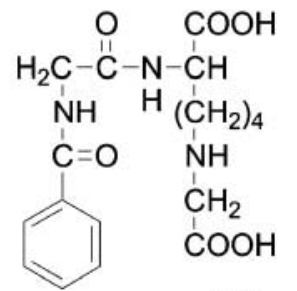

(d)
Fig. 1. Maillard compounds synthesised and used in the study. (a) $N^{\varepsilon}-(1-$ deoxy-D-fructosyl)-L-lysine, (b) $N^{\alpha}$-hippuryl- $N^{\varepsilon}$-(1-deoxy-D-fructosyl)-L-lysine, (c) $N^{\varepsilon}$-(carboxymethyl)-L-lysine, (d) $N^{\alpha}$-hippuryl- $N^{\varepsilon}$-(carboxymethyl)-L-lysine.

urinary excretion about $3 \%$ (Erbersdobler et al. 1991; Henle et al. 2000). The low faecal excretion is explained by limited proteolytic digestion and, more likely, metabolic activity of the intestinal flora (Erbersdobler et al. 1970; Wiame et al. 2002). In contrast to Amadori products, recent studies in our laboratory indicate enhanced bioavailability of selected AGE. For example, nearly all peptide-bound pyrraline supplied with the diet was found as free amino acid in the urine (Förster \& Henle, 2003). Koschinsky et al. (1997) discussed that serum AGE levels, as measured with ELISA, can be influenced by a diet containing AGE.

For dietary Maillard products to elicit effects within the human body, absorption in effectual amounts across the intestinal epithelial barrier is required. To the best of our knowledge, studies on the transepithelial transport of individual glycation compounds have not yet been performed.

In the present study, we tested the hypothesis that Maillard products are potential substrates for amino acid or peptide transporters. It has been well established in recent years that at the apical membrane of enterocytes at least six different systems are responsible for the uptake of amino acids and di- and tripeptides originating from protein digestion. The peptide transporter PEPT1 expressed in the luminal membrane of enterocytes is driven by a transmembrane $\mathrm{H}^{+}$gradient and catalyses the co-transport of its substrates with $\mathrm{H}^{+}$(for a review, see Daniel, 2004). PEPT1's naturally occurring substrates are di- and tripeptides. The recognition of exogenous compounds such as $\beta$-lactam antibiotics by PEPT1 (Bretschneider et al. 1999 ) is based on the phenomenon that these compounds possess peptide-like chemical structures. PEPT1 accepts many amino acid derivatives and modified dipeptides (Börner et al. 1998; Abe et al. 1999; Brandsch et al. 2004; Neumann et al. 2004).

Similarly, amino acid transport systems such as $\mathrm{B}^{0}, \mathrm{~B}^{0,+}$, $\mathrm{b}^{0,+}, \mathrm{y}^{+}$and PAT1 are candidates for AGE transport because they also might accept modified amino acids (Hatanaka et al. 2004; Metzner et al. 2004).

To study the intestinal transport of Maillard products, quantitatively relevant Maillard products were synthesised and characterised spectroscopically. In competition assays $v$. radiolabelled reference substrates, their interaction with the carriers responsible for the uptake of L-lysine, L-leucine and dipeptides was determined. Moreover, we measured the total transepithelial net flux of several relevant Maillard products across Caco-2 cell monolayers.

\section{Materials and methods}

\section{Materials}

The human colon carcinoma cell line Caco-2 was obtained from the German Collection of Micro-organisms and Cell Cultures (Braunschweig, Germany). Cell culture media and supplements and trypsin solution were purchased from Life Technologies, Inc. (Karlsruhe, Germany). Fetal bovine serum was from Biochrom (Berlin, Germany). [Glycine$1-{ }^{14} \mathrm{C}$ ]glycylsarcosine (Gly-Sar; specific radioactivity $1961 \mathrm{MBq} / \mathrm{mmol}$ ) and $\mathrm{L}-\left[4,5-{ }^{3} \mathrm{H}\right]$ lysine (specific radioactivity $3404 \mathrm{GBq} / \mathrm{mmol}$ ) were obtained from Amersham International (Little Chalfont, Bucks, UK), and $\mathrm{L}-\left[3,4,5^{3} \mathrm{H}(\mathrm{N})\right]$ leucine (specific radioactivity $5549 \mathrm{GBq} / \mathrm{mmol}$ ) from $\mathrm{NEN}^{\mathrm{TM}}$ Life Science Products, Inc. (Boston, MA, USA). $N^{\alpha}$-hippuryl-Llysine (HipLys), $N^{\alpha}$-t-butyloxycarbonyl-L-lysine and $N^{\alpha}$ acetyl-L-lysine were obtained from Bachem (Heidelberg, Germany). HPLC-grade methanol was from Riedel de Haen (Seelze, Germany). AG 50W-X8 ion exchange resin was from Bio-Rad Laboratories (Munich, Germany). $\mathrm{HCl}$ of 'ACS quality' was obtained from J. T. Baker (Deventer, The Netherlands). Furosine was from Neosystem (Strasbourg, France). Carboxypeptidase B (EC 3.4.17.2) (diisopropyl fluorophosphate-treated, $133 \mathrm{U} / \mathrm{mg}$ protein, $5 \mathrm{mg}$ protein $/ \mathrm{ml}$ ) and all other chemicals were purchased from Fluka (Taufkirchen, Germany). The water used for the preparation of buffers and solutions was obtained with a Purelab plus purification system (USFilter, Ransbach-Baumbach, Germany). All other chemicals were of highest purity available.

\section{Synthesis of Maillard products}

$\mathrm{N}^{\alpha}$-hippuryl- $\mathrm{N}^{\varepsilon}$-(1-deoxy-D-fructosyl)-L-lysine. The method described by Krause et al. (2003) with the modifications according to Seifert et al. (2004) was used. Briefly, HipLys was brought to reaction with anhydrous glucose in methanol to $\quad N^{\alpha}$-hippuryl- $N^{\varepsilon}$-(1-deoxy-D-fructosyl)-L-lysine (HipFruLys), followed by incubating the reaction mixture with carboxypeptidase B to remove remaining HipLys and subsequent purification of HipFruLys by semi-preparative reversed-phaseHPLC. Purity was checked using liquid chromatography-MS.

$\mathrm{N}^{\varepsilon}$-(1-deoxy-D-fructosyl)-L-lysine. The protocol published by Krause et al. (2003) was applied. Briefly, a mixture of $\mathrm{N}^{\alpha}$ Boc-L-lysine and glucose was incubated in the dry state, followed by semi-preparative cation-exchange chromatography using a mixture of pyridine and acetic acid as eluent. Liquid chromatography-MS and NMR were performed as described later. 
$\mathrm{N}^{\alpha}$-hippuryl $-\mathrm{N}^{\varepsilon}$-L-(carboxymethyl)-L-lysine. The synthesis was performed according to Liardon et al. (1987) with isolation of the product according to Krause et al. (2003) and Seifert et al. (2004). Dissolved in $20 \mathrm{ml}$ water were $5 \mathrm{mmol}$ HipLys and $6.5 \mathrm{mmol}$ glyoxylic acid monohydrate and the $\mathrm{pH}$ value was adjusted to 8.7 with $1 \mathrm{M}-\mathrm{NaOH}$. After adding $52 \mathrm{mg}$ palladium on charcoal, the reaction mixture was incubated for $29 \mathrm{~h}$ at $23^{\circ} \mathrm{C}$ and 20 bar under continuous stirring in a high-pressure autoclave. After this, the $\mathrm{pH}$ was adjusted to 7.0 using $2 \mathrm{M}-\mathrm{HCl}$ and the solvent was removed under reduced pressure. The dried residue was dissolved in $20 \mathrm{ml}$ water and applied to a column $(180 \times 18 \mathrm{~mm})$, filled with anion-exchanger Dowex 1X8 (acetate form; Bio-Rad, Munich, Germany), pre-equilibrated with 2 litres $1 \mathrm{M}-\mathrm{NaOH}$, 1 litre $1 \mathrm{M}$-acetic acid, 2 litres $2 \mathrm{M}$-acetic acid and 1 litre water at a flow rate of $60 \mathrm{ml} / \mathrm{h}$. After sample injection, the column was eluted with $350 \mathrm{ml} 0.5 \mathrm{M}$-acetic acid, 1 litre 1 $\mathrm{M}$-acetic acid and finally with $700 \mathrm{ml} 1.5 \mathrm{M}$-acetic acid at a flow rate of $30 \mathrm{ml} / \mathrm{h}$. Fractions of $6 \mathrm{ml}$ were collected. The presence of $N^{\alpha}$-hippuryl- $N^{\varepsilon}$-(carboxymethyl)-L-lysine (HipCML) in the collected fractions was detected by TLC with UV detection and reversed-phase HPLC as described earlier. Fractions containing HipCML were pooled, evaporated under reduced pressure, lyophilised and stored at $-20^{\circ} \mathrm{C}$.

$\mathrm{N}^{\varepsilon}$-(carboxymethyl)-L-lysine. The synthesis was performed as described earlier for HipCML, but using $N^{\alpha}$ acetyl-L-lysine instead of HipLys. After incubation in a high-pressure autoclave, the catalyst was removed by filtration, and after adding $20 \mathrm{ml} 6 \mathrm{M}-\mathrm{HCl}$, the solution was hydrolysed for $2 \mathrm{~h}$ at $120^{\circ} \mathrm{C}$. After cooling, the solution was evaporated to dryness under reduced pressure. The residue was dissolved in $50 \mathrm{ml}$ water, membrane filtered $(45 \mu \mathrm{m})$ and applied to a column $(180 \times 18 \mathrm{~mm})$ filled with cationexchanger AG 50WX8 $\left(\mathrm{H}^{+}\right.$form; Bio-Rad, Munich, Germany), pre-equilibrated with $250 \mathrm{ml} 6 \mathrm{M}-\mathrm{HCl}$ and $500 \mathrm{ml}$ water. At a flow rate of $30 \mathrm{ml} / \mathrm{h}$, the column was washed with $380 \mathrm{ml} 0.01 \mathrm{M}-\mathrm{HCl}$ to remove unbound material, followed by elution with $650 \mathrm{ml} 1 \mathrm{M}-\mathrm{HCl}, 550 \mathrm{ml} 1.5 \mathrm{M}-\mathrm{HCl}$ and $700 \mathrm{ml} 2 \mathrm{M}-\mathrm{HCl}$. Fractions of $6 \mathrm{ml}$ were collected. The presence of CML in the collected fractions was detected by TLC with ninhydrin as described later. Fractions containing CML were pooled, evaporated under reduced pressure, lyophilised and stored at $-20^{\circ} \mathrm{C}$.

\section{Cell culture}

Caco-2 cells were routinely cultured in $75 \mathrm{~cm}^{2}$ culture flasks with Minimum Essential Medium supplemented with $10 \%$ fetal bovine serum, gentamicin $(45 \mu \mathrm{g} / \mathrm{ml})$ and $1 \%$ non-essential amino acid solution (Börner et al. 1998; Knütter et al. 2004; Metzner et al. 2004). Subconfluent cultures (90\% of confluence) were treated for 5 min with Dulbecco's PBS followed by a 2 min incubation with trypsin solution. For most experiments, the cells were seeded in $35 \mathrm{~mm}$ disposable petri dishes (BD Biosciences, Heidelberg, Germany) at a density of $0.8 \times 10^{6}$ cells per dish. The uptake measurements were performed on day 7 after seeding. Protein content per dish was determined according to the Bradford method.

Caco- 2 cells were also cultured on permeable polycarbonate Transwell ${ }^{\circledR}$ cell culture inserts (diameter $24.5 \mathrm{~mm}$, pore size $3 \mu \mathrm{m}$; Costar GmbH, Bodenheim, Germany) (Bretschneider et al. 1999; Metzner et al. 2004). Subcultures were started at a cell density of 43000 cells $/ \mathrm{cm}^{2}$ and cultured for $21 \mathrm{~d}$. The lower (receiver) compartment contained $2.6 \mathrm{ml}$ medium and the upper (donor) compartment $1.5 \mathrm{ml}$ medium. The transepithelial electrical resistance was measured at day 21 using a Millicell ERS (Millipore Intertech, Bedford, MA, USA).

\section{Transport studies}

Uptake of $\left[{ }^{14} \mathrm{C}\right]$ Gly-Sar, L- $\left[{ }^{3} \mathrm{H}\right]$ leucine and $\mathrm{L}-\left[{ }^{3} \mathrm{H}\right]$ lysine in Caco-2 cells cultured on plastic dishes was measured at room temperature as described earlier (Börner et al. 1998; Bretschneider et al. 1999; Knütter et al. 2004). The uptake buffer contained $25 \mathrm{~mm} 2(\mathrm{~N}$-morpholino) ethane sulfonic acid-tri(hydroxymethyl)-aminomethane ( $\mathrm{pH}$ 6.0), $140 \mathrm{mM}$ -

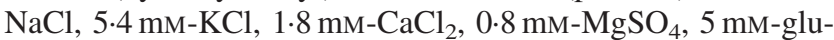
cose, radiolabelled reference substrates and unlabelled compounds at a concentration of mostly $10 \mathrm{~mm}$. After incubation for $10 \mathrm{~min}$, the cells were quickly washed four times, dissolved in Igepal CA-630 buffer and prepared for liquid scintillation spectrometry. The non-saturable component of $\left[{ }^{14} \mathrm{C}\right] \mathrm{Gly}$-Sar uptake (diffusion, adherent radioactivity) determined by measuring the uptake of $\left[{ }^{14} \mathrm{C}\right]$ Gly-Sar in the presence of $30 \mathrm{~mm}$-unlabelled Gly-Sar represented $11 \%$ of the total uptake. This value was taken into account during non-linear regression analysis of inhibition constants.

Transepithelial flux of Maillard products was measured as follows (Bretschneider et al. 1999; Metzner et al. 2004). All experiments were performed at day 21 after seeding at $37^{\circ} \mathrm{C}$ in a shaking water-bath. After washing the inserts with buffer (25 mM-HEPES-tri(hydroxymethyl)-aminomethane ( $\mathrm{pH} 7.5$ ), $140 \mathrm{~mm}-\mathrm{NaCl}, 5.4 \mathrm{~mm}-\mathrm{KCl}, 1.8 \mathrm{~mm}-\mathrm{CaCl}_{2}, 0.8 \mathrm{~mm}-$ $\mathrm{MgSO}_{4}, 5 \mathrm{~mm}$-glucose) for $10 \mathrm{~min}$, uptake was started by adding uptake buffer ( $\mathrm{pH} 6.0 ; 1.5 \mathrm{ml})$ containing compounds (mostly $5 \mathrm{~mm}$ ) to the donor side. At time intervals of 10, 30, 60 and $120 \mathrm{~min}, 200 \mu \mathrm{l}$ samples were taken from the receiver compartment and replaced with fresh buffer ( $\mathrm{pH} 7 \cdot 5)$. Samples were stored until analysis. After $2 \mathrm{~h}$, the filters were quickly washed four times with ice-cold uptake buffer, cut out of the plastic insert and stored in $1 \mathrm{ml}$ water and frozen.

L-Lysine, CML and FruLys were quantified in the uptake buffer and in the samples taken from the receiver compartment using ion-exchange chromatography and ninhydrin detection. HipFruLys and HipCML were measured using reversed-phase HPLC with direct UV detection (see later). Both methods allowed selective and sensitive measurement of the analytes within the samples.

The integrity of the Caco- 2 cell monolayers grown on permeable filters in the presence of Maillard products was verified by measuring the transepithelial electrical resistance. This method allows us to exclude membrane-damaging effects of the compounds which would lead to false high flux rates.

\section{Thin-layer chromatography}

TLC was carried out on pre-coated TLC plates SIL G-25 (Machery-Nagel, Düren, Germany). The solvent system was acetonitrile-water-acetic acid (80:20:20, by vol.). Visualisation was achieved by spraying the plates with $0.1 \%$ ninhydrin in ethanol, followed by heating at $90^{\circ} \mathrm{C}$ for $5 \mathrm{~min}$ or by 
spraying with $1 \%$ 2,3,5-triphenyl-2H-tetrazolium chloride in $1.0 \mathrm{M}-\mathrm{NaOH}$, followed by heating at $50^{\circ} \mathrm{C}$ for $2 \mathrm{~min}$. Alternatively, UV-absorbing compounds were detected under a UV lamp.

\section{Amino acid analysis}

Analysis of furosine, CML and the common amino acids was performed with an Alpha Plus amino acid analyser (LKB Biochrom, Cambridge, UK) using a $125 \times 4.6 \mathrm{~mm}$ peek column filled with ion-exchange resin series 686 (Laborbedarf K. Grüning, Olching, Germany). The composition of buffers, ninhydrin reagent and the running conditions are described by Henle et al. (1991). For external calibration of CML, $N^{\varepsilon}$-(carboxymethyl)-L-hippuryllysine was used as standard after acid hydrolysis and with glycine as internal reference.

\section{High-pressure liquid chromatography}

HPLC was performed with a gradient pump system (Knauer, Berlin, Germany) with online degasser, K1500 solvent organiser, K1001 pump, dynamic mixing chamber and a K2501 Knauer variable wavelength detector. Analytical separation of hippuryl derivatives was achieved using a stainless-steel column, $250 \times 4.6 \mathrm{~mm}$, filled with Knauer Eurospher 100, RP18-material of $5 \mu \mathrm{m}$ particle size, with integrated guard column $(5 \times 4 \mathrm{~mm})$ filled with the same material (Knauer, Berlin, Germany). The flow rate was $1.0 \mathrm{ml} / \mathrm{min}$ at $20^{\circ} \mathrm{C}$; detection was performed at $230 \mathrm{~nm}$. Solvent A was $0.01 \mathrm{M}-$ sodium phosphate buffer ( $\mathrm{pH} 7 \cdot 0$ ); solvent B was methanol. A linear gradient from $2 \% \mathrm{~B}$ to $6 \% \mathrm{~B}$ in $25 \mathrm{~min}$ was used.

Semi-preparative separation was performed using a stainless-steel column $(250 \times 8 \mathrm{~mm})$ with a guard column $(30 \times 8 \mathrm{~mm})$, both filled with Knauer Eurospher 100 RP18material of $10 \mu \mathrm{m}$ particle size (Knauer, Berlin, Germany). Flow rate was $1.5 \mathrm{ml} / \mathrm{min}$ at $20^{\circ} \mathrm{C}$; detection was performed at $280 \mathrm{~nm}$. The first chromatographic stage was performed isocratically with a mixture of $0.01 \mathrm{M}$-sodium phosphate buffer $(\mathrm{pH} 7 \cdot 0)$ and methanol $(90: 10, \mathrm{v} / \mathrm{v})$. The second stage was performed isocratically with a mixture of $0.05 \mathrm{M}$-acetic acid and methanol $(90: 10, \mathrm{v} / \mathrm{v})$.

\section{Nuclear magnetic resonance spectroscopy, mass spectrometry} and elemental analysis

${ }^{1} \mathrm{H}$ - and ${ }^{13} \mathrm{C}$-NMR spectra were recorded on a Bruker DRX 500 instrument (Bruker, Rheinstetten, Germany). Proton chemical shifts are relative to internal dimethyl sulfoxide for DMSO-d6 solutions or to internal deuterium-labelled water for ${ }^{2} \mathrm{H}$-labelled water solutions. Carbon chemical shifts are given relative to DMSO-d6 or to external standard tetramethylsilane for ${ }^{2} \mathrm{H}$-labelled water solutions. Assignments of ${ }^{1} \mathrm{H}$ and ${ }^{13} \mathrm{C}$ signals were based on two-dimensional NMR experiments as described in Krause et al. (2003).

For MS, a coupled liquid chromatography-electrospray ionisation MS system (Esquire-LC; Hewlett Packard-Bruker, Bremen, Waldbronn, Germany) was used; for elemental analysis a Euro EA 3000 elemental analyser (Eurovector, Milan, Italy) was used.

\section{Data analysis}

Experiments were done in duplicate or triplicate and each experiment was repeated two to three times. Results are given as means and their standard errors of the mean. Values of $50 \%$ inhibitory concentration ( $\mathrm{IC}_{50}$ values; i.e. concentration of unlabelled compounds necessary to inhibit $50 \%$ of $\left[{ }^{14} \mathrm{C}\right]$ Gly-Sar carrier-mediated uptake) were determined by non-linear regression (Knütter et al. 2004). Flux data were calculated after correction for the amount taken out by linear regression of appearance in the receiver well $v$. time.

\section{Results}

Syntheses

Syntheses resulted in all cases in chromatographically pure compounds. Results of NMR and MS were in agreement with published data (Krause et al. 2003) and confirmed the synthesis of these compounds. Elemental analysis gave the following results:

HipFruLys: $\mathrm{C}_{21} \mathrm{H}_{31} \mathrm{~N}_{3} \mathrm{O}_{9} \times 0.60 \quad \mathrm{CH}_{3} \mathrm{COOH} \times 1.30 \quad \mathrm{H}_{2} \mathrm{O}$ (molecular weight $528.94 \mathrm{Da}$ ); calculated: C, 50.41\%; H, $6.86 \%$; N, 7.94\%; found: C, 50.43\%; H, 6.54\%; N, 7.93\%;

FruLys: $\quad \mathrm{C}_{12} \mathrm{H}_{24} \mathrm{~N}_{2} \mathrm{O}_{7} \times 0.80 \quad \mathrm{CH}_{3} \mathrm{COOH} \times 0.80$ $\mathrm{CH}_{3} \mathrm{OH} \times 0.10 \mathrm{C}_{2} \mathrm{H}_{5} \mathrm{COCH}_{3}$ (molecular weight $389.21 \mathrm{Da}$ ); calculated: C, $45.67 \%$; $\mathrm{H}, 8.08 \%, \mathrm{~N}, 7.20 \%$; found: C, $45.40 \%$; H, $7.99 \%$; N, 7.17\%;

HipCML: $\quad \mathrm{C}_{17} \mathrm{H}_{23} \mathrm{~N}_{3} \mathrm{O}_{6} \times 0.40 \quad \mathrm{CH}_{3} \mathrm{COOH} \times 0.90 \quad \mathrm{H}_{2} \mathrm{O}$ (molecular weight $405.62 \mathrm{Da}$ ); calculated: $\mathrm{C}, 52.71 \%$; $\mathrm{H}$, $6.56 \%$; N, $10.36 \%$; found: C, $52.78 \%$; H, $6.38 \%$; N, 10.41\%;

CML: $\mathrm{C}_{8} \mathrm{H}_{16} \mathrm{~N}_{2} \mathrm{O}_{4} \times 0.300 .8 \mathrm{H}_{2} \mathrm{O} \times 0.20 \mathrm{NH}_{4} \mathrm{Cl} \times 2 \mathrm{HCl}$ (molecular weight 293.25 Da); calculated: C, 32.77\%; H, $6.67 \%$; N, $10.51 \%$; found: C, $32.90 \%$;, $6.81 \%$; N, $10.49 \%$.

All isolates contained small amounts of water and acetate, the latter resulting from chromatographic separation of the final products. FruLys additionally contained traces of methanol. Free CML was purified via ion-exchange chromatography as the corresponding dihydrochloride, containing traces of ammonia.

\section{Inhibition of $\left[{ }^{14}\right.$ C]glycylsarcosine uptake}

We investigated whether Maillard products represent potential substrates for the intestinal $\mathrm{H}^{+}$-peptide co-transporter PEPT1. This was done in competition experiments using radiolabelled Gly-Sar as reference substrate of the transport system. Several Maillard products at a concentration of $10 \mathrm{~mm}$ were able to inhibit $\mathrm{H}^{+}$-dependent uptake of $\left[{ }^{14} \mathrm{C}\right] \mathrm{Gly}$-Sar. CML, HipFruLys, HipCML and FruLys inhibited $\left[{ }^{14} \mathrm{C}\right] \mathrm{Gly}-\mathrm{Sar}$ uptake into Caco-2 cells by 13 to $45 \%$ (Fig. 2). HipLys, which was used as control for unmodified peptide-bound lysine, behaved similarly. Lysinoalanine had no significant effect. The inhibitor showing the highest apparent inhibitory potency was FruLys. In a dose-response type competition assay we determined an $\mathrm{IC}_{50}$ value of 8.7 (SEM 2.2) mM for $\left[{ }^{14} \mathrm{C}\right] \mathrm{Gly}-\mathrm{Sar}$ uptake inhibition (Fig. 3). This value reflects a rather low affinity of FruLys to PEPT1 according to our classification (Brandsch et al. 2004). For comparison, we also measured the interaction of L-lysine and the dipeptide Ala-Lys with PEPT1. Whereas the amino acid L-lysine shows no affinity 


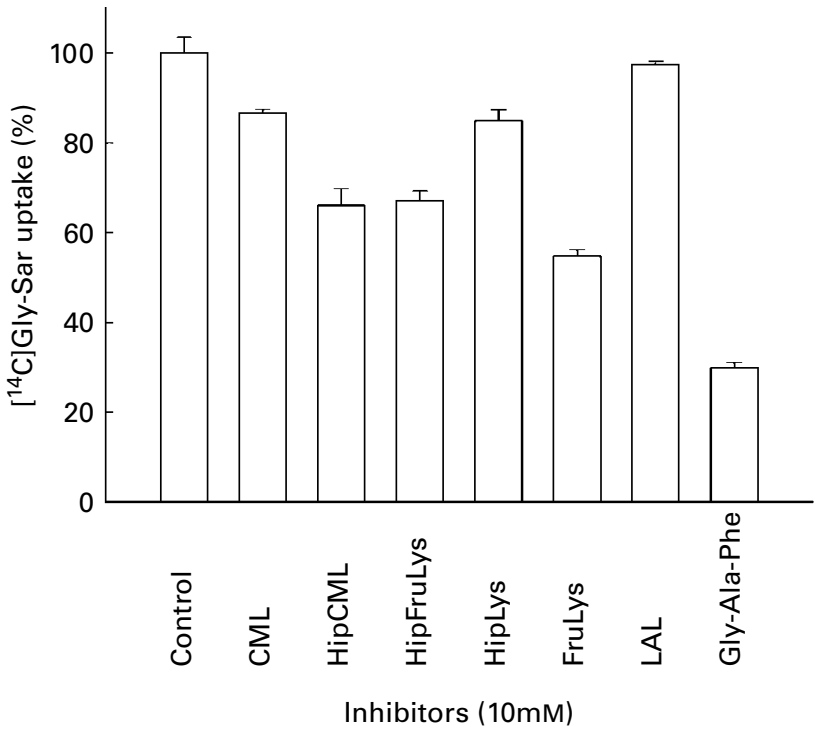

Fig. 2. Inhibition of $\left[{ }^{14} \mathrm{C}\right]$ glycylsarcosine $\left(\left[{ }^{14} \mathrm{C}\right] \mathrm{Gly}\right.$-Sar) uptake by Maillard products and Gly-Ala-Phe in Caco-2 cells. Uptake of $10 \mu \mathrm{M}-\left[{ }^{14} \mathrm{C}\right] \mathrm{Gly}$-Sar was measured for $10 \mathrm{~min}$ in monolayer cultures of Caco-2 cells at $\mathrm{pH} 6.0$ in the absence (control) or presence of $10 \mathrm{~mm}$ of the compounds. Uptake of $\left[{ }^{14} \mathrm{C}\right]$ Gly-Sar measured in the absence of the inhibitors was taken as $100 \%$ (165 (SEM 8) pmol/10 min per mg protein). Data are means ( $n 3-4)$, with their standard errors represented by vertical bars. CML, $N^{\varepsilon}$-(carboxymethyl)-Llysine; HipCML, $N^{\alpha}$-hippuryl- $N^{\varepsilon}$-(carboxymethyl)-L-lysine; HipFruLys, $N^{\alpha}$-hippuryl- $N^{\varepsilon}$-(1-deoxy-D-fructosyl)-L-lysine; HipLys, $N^{\alpha}$-hippuryl-L-lysine; FruLys, $N^{\varepsilon}$-(1-deoxy-D-fructosyl)-L-lysine; LAL, lysinoalanine.

to PEPT1, Ala-Lys represents a high affinity PEPT1 substrate $\left(\mathrm{IC}_{50} 0 \cdot 31\right.$ (SEM 0.07) $\mathrm{mM}$ ).

\section{Inhibition of amino acid uptake}

In a similar approach, we tested the ability of the Maillard products to inhibit L-leucine and L-lysine uptake. Uptake of $\mathrm{L}-\left[{ }^{3} \mathrm{H}\right]$ lysine was weakly inhibited by CML (30 mM) and HipLys (10 mM). FruLys, unlabelled L-lysine and L-leucine

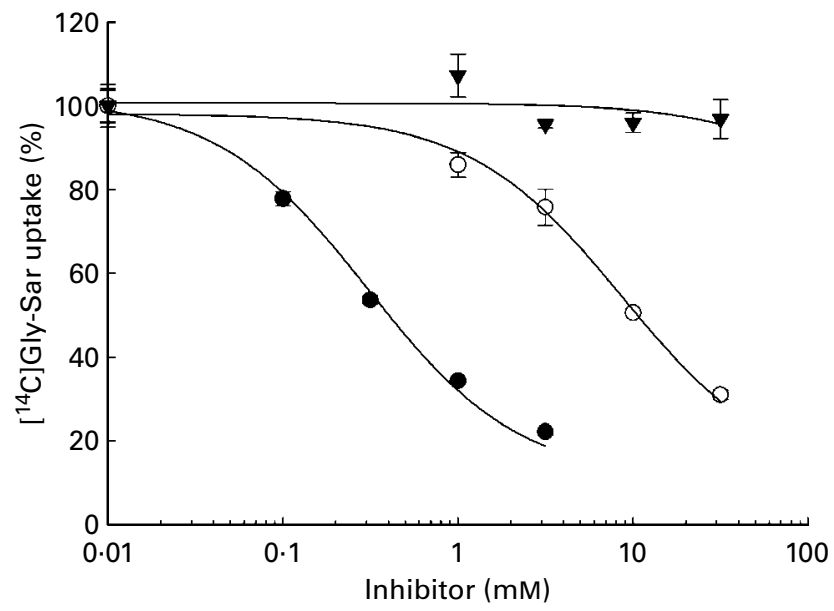

Fig. 3. Inhibition of $\left[{ }^{14} \mathrm{C}\right]$ glycylsarcosine $\left(\left[{ }^{14} \mathrm{C}\right] \mathrm{Gly}\right.$-Sar) uptake in Caco-2 cells. Uptake of $10 \mu \mathrm{M}-\left[{ }^{14} \mathrm{C}\right] \mathrm{Gly}$-Sar was measured for $10 \mathrm{~min}$ in monolayer cultures of Caco-2 cells at $\mathrm{pH} 6.0$ in the absence (control) or presence of 0 $31.6 \mathrm{~mm}$-Ala-Lys $(\bullet)$, L-lysine $(\mathbf{\nabla})$ and $N^{\varepsilon}$-(1-deoxy-D-fructosyl)-L-lysine $(O)$. Data are means $(n 3-4)$, with their standard errors represented by vertical bars. inhibited the uptake of $\mathrm{L}-\left[{ }^{3} \mathrm{H}\right]$ lysine by 81,90 and $84 \%$, respectively. HipCML had no effect (Fig. 4).

None of the compounds was able to inhibit the uptake of L- $\left[{ }^{3} \mathrm{H}\right]$ leucine by more than $15 \%$ (Fig. 5). For comparison and to verify the experimental conditions, inhibition of $\mathrm{L}$ $\left[{ }^{3} \mathrm{H}\right]$ leucine uptake by L-leucine and L-lysine was measured. Uptake was inhibited by L-leucine $(10 \mathrm{~mm})$ by $81 \%$ and by L-lysine (10 mM) by $18 \%$.

\section{Transepithelial flux}

At a concentration of $5 \mathrm{~mm}$, none of the compounds showed negative effects on the transepithelial electrical resistance of Caco-2 monolayers (Table 1). With regard to their own flux, even after $2 \mathrm{~h}$ the basolateral amounts of CML and HipFruLys were below the detection limit (Table 1). No flux rates could be calculated. Flux rates of HipCML, FruLys and lysinoalanine were between 0.008 and $0.26 \% / \mathrm{cm}^{2}$ per $\mathrm{h}$ (Table 1). Hence, only the flux of HipCML was higher than the flux of the space marker $\left[{ }^{14} \mathrm{C}\right]$ mannitol.

No significant amounts of Maillard products were found in Caco- 2 cell monolayers cut out of the inserts after $2 \mathrm{~h}$. The results were supported by quantification of the Maillard products in the donor compartment during the experiments. No decrease of the starting concentration of $5 \mathrm{~mm}$ due to transport into the lower compartment could be observed. These measurements concomitantly confirmed the stability of the compounds over $2 \mathrm{~h}$ in the uptake buffer contacting the brush-border membrane of the cells.

\section{Discussion}

The present results show that the intestinal transport of the Maillard products and AGE investigated in the present study

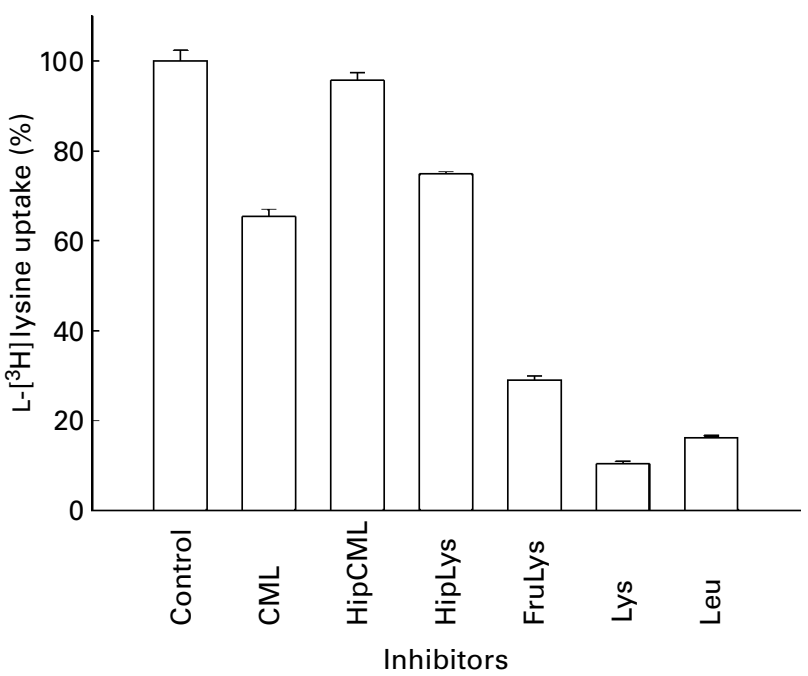

Fig. 4. Inhibition of L- $\left[{ }^{3} \mathrm{H}\right]$ lysine uptake by Maillard products, and L-leucine (Leu) and L-lysine (Lys) in Caco-2 cells. Uptake of $2 \mathrm{nM}-\mathrm{L}-\left[{ }^{3} \mathrm{H}\right] \mathrm{lysine}$ was measured for $10 \mathrm{~min}$ in monolayer cultures of Caco-2 cells at $\mathrm{pH} 6.0$ in the absence (control) or presence of $10 \mathrm{~mm}$ of the compounds $\left(N^{\varepsilon}\right.$-(carboxymethyl)-L-lysine (CML), $30 \mathrm{~mm})$. Uptake of L-[ $\left[{ }^{3} \mathrm{H}\right]$ lysine measured in the absence of the inhibitors (49 (SEM 7) fmol/10 min per mg protein) was taken as $100 \%$. Data are means $(n 3-4)$, with their standard errors represented by vertical bars. HipCML, $N^{\alpha}$-hippuryl- $N^{\varepsilon}$-(carboxymethyl)-L-lysine; HipLys, $N^{\alpha}$-hippuryl-L-lysine; FruLys, $N^{\varepsilon}$-(1-deoxy-D-fructosyl)-L-lysine. 


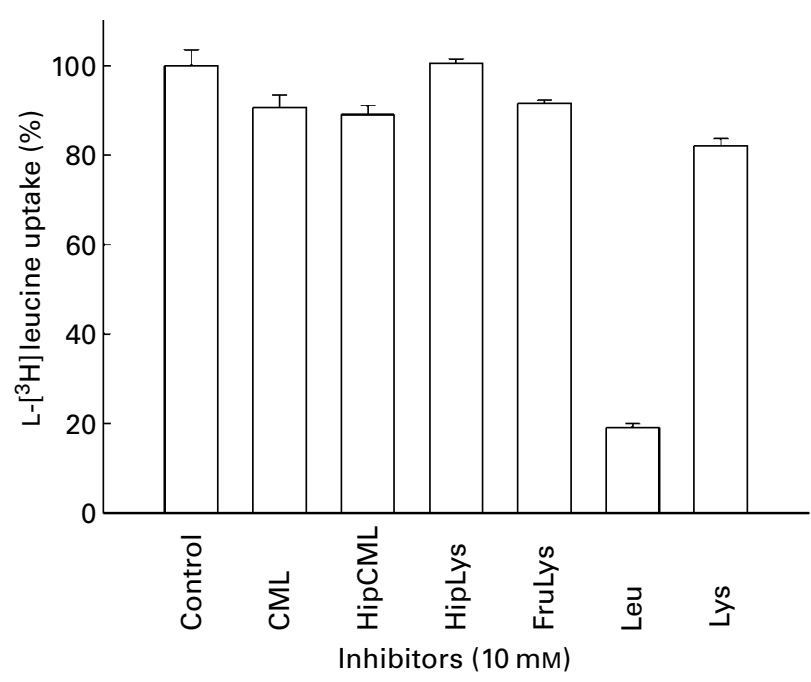

Fig. 5. Inhibition of L- $\left[{ }^{3} \mathrm{H}\right]$ leucine uptake by Maillard products and L-leucine (Leu) and L-lysine (Lys) in Caco-2 cells. Uptake of $1.2 \mathrm{nM}-\mathrm{L}-\left[{ }^{3} \mathrm{H}\right]$ leucine was measured for $10 \mathrm{~min}$ in monolayer cultures of Caco-2 cells at $\mathrm{pH} 6.0$ in the absence (control) or presence of $10 \mathrm{~mm}$ of the compounds. Uptake of $\mathrm{L}-\left[{ }^{3} \mathrm{H}\right]$ leucine measured in the absence of the inhibitors (120 (SEM 6) fmol/ $10 \mathrm{~min}$ per $\mathrm{mg}$ protein) was taken as $100 \%$. Data are means $(n 4)$, with their standard errors represented by vertical bars. CML, $N^{\varepsilon}$-(carboxymethyl)-L-lysine; HipCML, $N^{\alpha}$-hippuryl- $N^{\varepsilon}$-(carboxymethyl)-L-lysine; HipLys, $N^{\alpha}$-hippuryl-L-lysine; FruLys, $N^{\varepsilon}$-(1-deoxy-D-fructosyl)-L-lysine.

is low and not mediated by amino acid and peptide carriers. The type of compounds and the concentrations applied here in vitro correspond to the human physiological situation in vivo after food intake. We selected the quantitatively predominant Amadori product of lysine FruLys, its oxidative degradation product CML and, to investigate the influence of $N$-terminal modification, their corresponding hippuryl derivatives HipFruLys and HipCML. With regard to the concentrations, the range of 1 to $30 \mathrm{~mm}$ is conceivable considering the fact that, for example, the daily CML intake in human consumers can be as high as $30 \mathrm{mg}$. Similarly, Amadori products of L-lysine in milk can reach concentrations as high as $2 \mathrm{~mm}$ (Henle, 2003).

CML, HipCML, HipFruLys, HipLys and lysinoalanine inhibit the total $\left[{ }^{14} \mathrm{C}\right]$ Gly-Sar uptake in Caco- 2 cells only by 3 to $34 \%$. Since it has been shown unequivocally that the uptake of $\left[{ }^{14} \mathrm{C}\right] \mathrm{Gly}-\mathrm{Sar}$ into Caco-2 cells is mediated by a single transport system which has been identified as the low-affinity, high-capacity intestinal system PEPT1 (Daniel, 2004; Brandsch et al. 2004) we conclude that PEPT1 can be ruled out as transport system for the Maillard products.

The affinity constant of FruLys, the strongest inhibitor, at PEPT1 was $9 \mathrm{~mm}$. It should be noted that in this assay natural di- and tripeptides display $\mathrm{IC}_{50}$ values of 0.1 to $0.3 \mathrm{~mm}$ as shown here for Ala-Lys. Inhibitors with $\mathrm{IC}_{50}$ values of $>15 \mathrm{~mm}$ are not considered substrates; for $\beta$-lactam antibiotics it has been shown that in general only those compounds with an $\mathrm{IC}_{50}$ value at PEPT1 of $<14 \mathrm{mM}$ are transported by this carrier across the Caco- 2 cell monolayer and that the transport rate corresponds very well with the oral availability. Compounds with an $\mathrm{IC}_{50}$ (approximately $\mathrm{K}_{\mathrm{i}}$ in these assays) of $>15 \mathrm{~mm}$ have to be administered parenterally. Hence, FruLys can be considered a low-affinity PEPT1 inhibitor or a low-affinity PEPT1 substrate.
Table 1. Transepithelial flux of Maillard products (all $5 \mathrm{~mm}$ ) and reference compounds $(10 \mathrm{~nm}-30 \mu \mathrm{M})$ across Caco- 2 cell monolayers* (Mean values with their standard errors)

\begin{tabular}{|c|c|c|c|c|}
\hline \multirow[b]{2}{*}{ Compound } & \multicolumn{2}{|c|}{$\begin{array}{c}\text { Transepithelial } \\
\text { resistance } \\
\left(\Omega \times \mathrm{cm}^{2}\right)\end{array}$} & \multicolumn{2}{|c|}{$\begin{array}{l}\text { Transepithelial flux } \\
\left.\qquad \% / \mathrm{cm}^{2} \text { per } \mathrm{h}\right)\end{array}$} \\
\hline & Mean & SEM & Mean & SEM \\
\hline Control & 605 & 8 & & \\
\hline HipCML & 592 & 42 & 0.26 & 0.08 \\
\hline CML & 610 & 18 & $<\mathrm{dl}$ & \\
\hline HipFruLys & 645 & 22 & $<\mathrm{dl}$ & \\
\hline FruLys & 679 & 9 & 0.008 & 0.003 \\
\hline LAL & 707 & 11 & 0.02 & 0.01 \\
\hline$\left[{ }^{14} \mathrm{C}\right]$ mannitol & & & 0.07 & $0.002 \dagger$ \\
\hline$\left[{ }^{14} \mathrm{C}\right]$ Gly-Sar & & & 1.4 & $0.1 \dagger$ \\
\hline $\mathrm{I}-\left[{ }^{3} \mathrm{H}\right]$ proline & & & $5 \cdot 3$ & $0.4 \ddagger$ \\
\hline
\end{tabular}

HipCML, $\quad N^{\alpha}$-hippuryl- $N^{\varepsilon}$-(carboxymethyl)-L-lysine; CML, $\quad N^{\varepsilon}$-(carboxymethyl)-Llysine; <dl, below detection limit (HPLC, amino acid analysis); HipFruLys, $N^{\alpha}-$ hippuryl- $N^{\varepsilon}$-(1-deoxy-D-fructosyl)-L-lysine; FruLys, $N^{\varepsilon}$-(1-deoxy-D-fructosyl)-Llysine; LAL, lysinoalanine; Gly-Sar, glycylsarcosine.

* Substances were added to the donor compartment $(1.5 \mathrm{ml})$ of Transwell systems in uptake buffer $(\mathrm{pH} 6.0)$. Samples $(200 \mu \mathrm{l})$ were taken from the receiver compartment $(\mathrm{pH} \mathrm{7.5)}$ and analysed as described (p. 1224) or by liquid scintillation counting ( $n$ 4; resistance, $n 3$ ).

† Value from Bretschneider et al. (1999).

$\ddagger$ Value from Metzner et al. (2004).

With the possible exception of FruLys, the Maillard products tested in the present study are not substrates for the amino acid carriers responsible for the uptake of the amino acids L-lysine and L-leucine. None of the compounds was able to inhibit the uptake of $\mathrm{L}-\left[{ }^{3} \mathrm{H}\right]$ leucine by more than $15 \%$. Uptake of L- $\left[{ }^{3} \mathrm{H}\right]$ lysine was not inhibited by HipCML; low inhibition was observed with CML (30 mM) and HipLys $(10 \mathrm{~mm})$. FruLys $(10 \mathrm{~mm})$, on the other hand, inhibited Llysine uptake strongly by $81 \%$.

With regard to the amino transport systems involved in Lleucine and L-lysine uptake (Brandsch \& Brandsch, 2003) we conclude from the substrate specificity results that Llysine is mainly transported by system $\mathrm{B}^{0,+}$ or system $b^{0,+}$ because L-leucine inhibited the L-lysine uptake strongly by $84 \%$. L-Leucine seems to be transported mainly by $\mathrm{B}^{0}$ because the $\mathrm{L}-\left[{ }^{3} \mathrm{H}\right]$ leucine uptake was inhibited by $81 \%$ by unlabelled L-leucine itself but only $18 \%$ by $10 \mathrm{mM}$-L-lysine.

Measurement of Gly-Sar, L-lysine and L-leucine uptake in the presence of Maillard products only allows estimation of their potency for dipeptide or amino acid uptake inhibition, for example, their apparent affinity to the systems. The results do not allow the conclusion that the effective compound inhibiting uptake of reference substrates are indeed transported by the systems across the cell membrane. We therefore performed the flux studies described. Importantly, the Maillard products tested in the present study did not affect the integrity of the Caco-2 monolayers. They did not damage the cells or the cell junctions. In addition, they do not seem to affect the cell membrane fluidity to a significant extent. It is therefore concluded from the results that the transepithelial electrical resistance was not changed by the compounds.

The apical to basolateral transepithelial flux rates of Maillard products at apical concentrations of $5 \mathrm{~mm}$ ranged from 0.01 to $0.3 \% / \mathrm{cm}^{2}$ per h. They were much lower than the flux rates of Gly-Sar, L-phenylalanine (data not shown), L-proline 
and mannitol: In previous studies we determined a reference flux rate of $\left[{ }^{14} \mathrm{C}\right]$ mannitol across Caco- 2 cell monolayers of 0.07 (SEM 0.002$) \% / \mathrm{cm}^{2}$ per h (Bretschneider et al. 1999). For comparison, the flux of $\left[{ }^{14} \mathrm{C}\right] \mathrm{Gly}-\mathrm{Sar}$ was found to be 20-fold higher: At a substrate concentration of $30 \mu \mathrm{M}$, 616.9 (SEM 39.6) $\mathrm{pmol} / \mathrm{cm}^{2}$ per h was measured at the receiver side of the monolayers $\left(1.4 \% / \mathrm{cm}^{2}\right.$ per h). Flux of $\mathrm{L}-\left[{ }^{3} \mathrm{H}\right]$ proline in another study was $5 \cdot 3(\mathrm{SEM} 0.4) \% / \mathrm{cm}^{2}$ per h (Metzner et al. 2004). Mannitol serves in such studies as a non-transported space marker. For Gly-Sar and L-proline, active, proton-dependent uptake at the apical membrane has been demonstrated unequivocally (Daniel, 2004; Knütter et al. 2004; Metzner et al. 2004). Comparing these flux rates, we have to conclude that the Maillard products tested do not reach the basolateral side of enterocytes in significant amounts.

Even though FruLys displays a relatively high affinity to the L-lysine transport system(s), its transport across the epithelium is negligible. FruLys possesses a free $\alpha$-amino terminus and carboxy terminus. As we have shown recently, side-chain-protected Lys-Ala dipeptides such as Lys(Boc)-Ala and Lys(z)Ala also display affinity to PEPT1 but are not transported by the system (Knütter et al. 2004). Abe et al. (1999) synthesised and tested dipeptide analogues conjugated at the $\varepsilon$-amino group of L-lysine in Val-Lys or Lys-Sar with fluorescent compounds such as fluorescein isothiocyanate and coumarin-3-carboxylic acid. These analogues inhibited the Gly-Sar uptake by Caco- 2 cells with very high affinity but are not transported. In further studies, we will test whether FruLys as the C-terminal group of a dipeptide is recognised and transported by PEPT1; Kottra et al. (2002) have shown that the binding site of PEPT1 is asymmetric in the sense that side-chain modifications of $\mathrm{L}$ lysine are tolerated when L-lysine is the C-terminal amino acid.

In conclusion, the present study shows that the transepithelial net flux of Maillard products across Caco- 2 cell monolayers is low. Carriers for dipeptides, L-lysine and L-leucine do not seem to be involved. The integrity of cell monolayers was not affected by Maillard products at a concentration of $5 \mathrm{~mm}$. The low transepithelial flux measured for these compounds occurs most probably by simple diffusion.

\section{Acknowledgements}

The present study was supported by Land Sachsen-Anhalt grant 3505A/0403L and by Bundesministerium für Bildung und Forschung grant no. 0312750A.

\section{References}

Abe H, Satoh M, Miyauchi S, Shuto S, Matsuda A \& Kamo N (1999) Conjugation of dipeptide to fluorescent dyes enhances its affinity for a dipeptide transporter (PEPT1) in human intestinal Caco-2 cells. Bioconjug Chem 10, 24-31.

Börner V, Fei Y-L, Hartrodt B, Ganapathy V, Leibach FH, Neubert K \& Brandsch M (1998) Transport of amino acid aryl amides by the intestinal $\mathrm{H}^{+}$/peptide cotransport system, PEPT1. Eur J Biochem 255, 698-702.

Brandsch M \& Brandsch C (2003) Intestinal transport of amino acids, peptides and proteins. In Progress in Research on Energy and Protein Metabolism, pp. 667-680 [WB Souffrant and CC Metges, editors]. Wageningen, The Netherlands: Wageningen Academic Publishers.

Brandsch M, Knütter I \& Leibach FH (2004) The intestinal $\mathrm{H}^{+} /$peptide symporter PEPT1, structure-affinity relationships. Eur $J$ Pharm Sci 21, 53-60.

Bretschneider B, Brandsch M \& Neubert R (1999) Intestinal transport of $\beta$-lactam antibiotics: analysis of the affinity at the $\mathrm{H}^{+}$/peptide symporter (PEPT1), the uptake into Caco-2 cell monolayers and the transepithelial flux. Pharm Res 16, 55-61.

Daniel H (2004) Molecular and integrative physiology of intestinal peptide transport. Annu Rev Physiol 66, 361-384.

Erbersdobler HF \& Faist V (2003) Maillard reaction products: uptake, metabolic transit and selected parameters of biopotency and safety. Forum Nutr 56, 353-355.

Erbersdobler H, Gunsser I \& Weber G (1970) Degradation of fructoselysine by the intestinal flora. Zentralbl Veterinaermed $\mathbf{1 7 A}$, $573-575$.

Erbersdobler HF, Lohmann M \& Buhl K (1991) Utilization of early Maillard reaction products by humans. Adv Exp Med Biol 289, 363-370.

Finot PA \& Magnenat E (1981) Metabolic transit of early and advanced Maillard products. Prog Food Nutr Sci 5, 193-207.

Förster A \& Henle T (2003) Glycation in food and metabolic transit of dietary AGE: studies on urinary excretion of pyrraline. Biochem Soc Trans 31, 1383-1385.

Friedman M (1996) Food browning and its prevention. J Agric Food Chem 4, 631-653.

Gerrard JA (2002) New aspects of an ageing chemistry-recent developments concerning the Maillard reaction. Austral J Chem 55, 299-310.

Hatanaka T, Haramura M, Fei YJ, Miyauchi S, Bridges CC, Ganapathy PS, Smith SB, Ganapathy V \& Ganapathy ME (2004) Transport of amino acid-based prodrugs by the $\mathrm{Na}^{+}$- and $\mathrm{Cl}^{-}$-coupled amino acid transporter $\mathrm{ATB}^{0,+}$ and expression of the transporter in tissues amenable for drug delivery. J Pharmacol Exp Ther 308, 1138-1147.

He C, Sabol J, Mitsuhashi T \& Vlassara H (1999) Dietary glycotoxins: inhibition of reactive products by aminoguanidine facilitates renal clearance and reduces tissue sequestration. Diabetes 48 , $1308-1315$.

Henle T (2003) AGE in foods: do they play a role in uremia? Kidney Int Suppl 84, S145-S147.

Henle T \& Miyata T (2003) Advanced glycation end products in uremia. Adv Ren Repl Ther 10, 321-331.

Henle T, Schwenger V \& Ritz E (2000) Studies on the renal handling of lactuloselysine from milk products. Czech J Food Sci 18, $101-102$.

Henle T, Walter H, Krause I \& Klostermeyer H (1991) Efficient determination of individual Maillard compounds in heat-treated milk products by amino acid analysis. Int Dairy $J \mathbf{1}$, $125-135$.

Knütter I, Hartrodt B, Theis S, Foltz M, Rastetter M, Daniel H, Neubert K \& Brandsch M (2004) Analysis of the transport properties of side chain modified dipeptides at the mammalian peptide transporter PEPT1. Eur J Pharm Sci 21, 61-67.

Koschinsky T, He CJ, Mitsuhashi T, Bucala R, Liu C, Buenting C, Heitmann K \& Vlassara H (1997) Orally absorbed reactive glycation products (glycotoxins): an environmental risk factor in diabetic nephropathy. Proc Natl Acad Sci USA 94, 6474-6479.

Kottra G, Stamfort A \& Daniel H (2002) PEPT1 as a paradigm for membrane carriers that mediate electrogenic bidirectional transport of anionic, cationic, and neutral substrates. J Biol Chem 277, 32683-32691.

Krause R, Knoll K \& Henle T (2003) Studies in the formation of furosine and pyridosine during acid hydrolysis of different Amadori products of lysine. Eur Food Res Technol 216, 277-283. 
Liardon R, De Weck-Godard D, Philipossian G \& Finot PA (1987) Identification of $\mathrm{N}^{\varepsilon}$-carboxymethyllysine: a new Maillard reaction product in rat urine. J Agric Food Chem 35, 427-431.

Metzner L, Kalbitz J \& Brandsch M (2004) Transport of pharmacologically active proline derivatives by the human protoncoupled amino acid transporter hPAT1. J Pharmacol Exp Ther 309, 28-35.

Neumann J, Bruch M, Gebauer S \& Brandsch M (2004) Transport of the phosphonodipeptide alafosfalin by the $\mathrm{H}^{+}$/peptide cotransporters PEPT1 and PEPT2 in intestinal and renal epithelial cells. Eur J Biochem 271, 2012-2017.
Raj DS, Choudhury D, Welbourne TC \& Levi M (2000) Advanced glycation end products: a nephrologist's perspective. Am J Kidney Dis 35, 365-380.

Seifert S, Krause R, Gloe K \& Henle T (2004) Studies on the metal complexation of the peptide-bound Maillard reaction products $\mathrm{N}^{\varepsilon}$ fructoselysine and $\mathrm{N}^{\varepsilon}$-carboxymethyllysine. J Agric Food Chem 52, 2347-2350.

Valle-Riestra J \& Barnes RH (1970) Digestion of heat-damaged egg albumen by the rat. $J$ Nutr 100, 873-882.

Wiame E, Delpierre G, Collard F \& van Schaftingen E (2002) Identification of a pathway for the utilization of the Amadori product fructoselysine in Escherichia coli. J Biol Chem 277, 42523-42529. 